\title{
THE END OF NATIONAL CINEMA
}

\author{
Interesting Discussions and Unfulfilled Promises
}

\author{
Jasmine Agnes T. Cruz \\ Ateneo de Manila University \\ jtcruz@ateneo.edu
}

With the rise of independent filmmakers, to Filipinos winning awards in international film festivals such as The Cannes Film Festival, The Berlin Film Festival, and The Venice Film Festival, and with the 2016 Metro Manila Film Festival saying that they chose quality films over commercial considerations, one can say that the local film industry is in the midst of exciting developments. Thus, it was interesting to peruse the pages of a new book on Philippine cinema. Patrick F. Campos's The End of National Cinema: Filipino Film at the Turn of the Century (UP Press, 2016) mainly discusses the films of the first decade of the 21st century, a period where many of its undercurrents such as themes discussed in the films, leading directors, and industry issues that beset filmmakers, and the like, still flow into our present day.

Throughout the book, Campos, a film critic and an assistant professor at the University of the Philippines, discussed several Filipino filmmakers, Cinemalaya and how it affected the industry, depictions of urban realism in film, how rural landscapes are represented in film, the developments in the Asian film circle and the rest of the world, the political and social impact of films, filmic folklore, the dearth of the depiction of the Philippine-American war in movies and the importance of having this historical event be represented in film, and more. All of these discussions were supposed to put forward the book's central theme which is encapsulated in the title. In his introduction, it was not clear what he means by the end of national cinema. Later on, we begin to surmise that he is talking about either collaborations between filmmakers and actors from different countries, appreciation by film audiences that come from foreign countries, understanding of the film in terms of a limited national context, the impact of international film festival such as the ones mentioned above, among others.

The introductory chapter where one expects to understand the groundwork of the book begins by discussing the Southeast Asian film circuit. There are several 
paragraphs each devoted to Vietnam, Singapore, Thailand, and other countries in Southeast Asia. There is discussion on how each of these countries are going beyond their national borders through cross-country collaborations and other initiatives. Film festivals are said to also act as a means for countries to go beyond the national and instead adopt international standards. With this overview on what is happening to the rest of Asia, the reader will wonder how such trends are reflected in the Philippine context. The reader hopes she has the rest of the book to find out.

Throughout the book, one will notice the commendable amount of information that Campos delivers. He discusses films such as Ishmael Bernal's Manila by Night (1980), Mike de Leon's Bayaning 3rd World (Third World Hero) (1999), Kidlat Tahimik's Bakit Dilaw ang Gitna ng Bahaghari? (Why is Yellow the Middle of the Rainbow?) (1994). One interesting discussion is on Ishmael Bernal's Manila by Night, where Campos talks about the socio-political forces that were reflected in the film and how the powers that be reacted to it. That discussion centered on the Marcos regime which, at the film's release in 1980, had already declared Martial Law thereby prolonging Ferdinand Marcos, Sr.s hold on power. The Marcoses had a vision for Manila. They wanted to modernize it and let it be a paragon of progress. Anything that counters this vision ruins them. Inconveniently for them, the blight of Manila continued to persist and this was reflected in Manila by Night. Campos identifies this reflection as a form of thirdspace, or "a luminal, inconclusive, complex, dynamic space and even counterspace, both literal and symbolic, that is fertile ground for critical activity." The film's depiction of the grimy reality of Manila went against the dictator's desire to paint the country as a land of progress. To show his disapproval, Marcos banned the film from competing in Berlin, which could have earned the film more legitimacy and thus more eyes could have been focused on the reality of poverty in the country.

Those kinds of analysis by Campos can enrich the reader's understanding of the film, but certain parts the book are peppered with too much information. Blocks of paragraphs, such as the repeating paragraphs listing the names of films that fall under a certain category, could have been relegated to footnotes or endnotes to be perused by a more eager reader. In this way, one could have avoided sacrificing the hard work that Campos did but, at the same time, would have made sure that such information did not obstruct one's reading pleasure.

The book is written by an academic, so this writer braced herself as she anticipated jargonic text that will be hard to digest. Instead, this writer found many lucid sentences such as when he discusses Ishmael Bernal's 1980 film Manila by Night. Campos vividly describes how the film showed the labyrinthine chaos of Manila's streets. Campos zeroes in on a scene where the police ask a blind masseuse named

Kritika Kultura 28 (2017): -313

(c) Ateneo de Manila University

<http://journals.ateneo.edu/ojs/kk/> 
Bea where the fugitive named Kano ran towards. In response, Bea gives a convoluted set of instructions, thus highlighting the quagmire that is Manila. As the viewer watches Kano, and another character named Alex who incidentally got caught up in the chase, as they run through the roofs, the narrow alleys, winding streets, to Central Bank, and Harrison Plaza, the viewers realize something. Campos is saying that these characters know the chaotic streets of Manila so well. Maybe this is the reason why these "unlivable spaces" are tolerated. As when one lives in such a maze, even the blind has more knowledge and thus power over the police. After taking us through the rush of this scene, Campos ends with a breathless pause. "As soon as Alex finds himself free and safe, he begins to pace leisurely, apparently aimlessly, but actually toward Rizal Park," said Campos. "Alex lies down on well-kept grass and shuts his eyes before Manila by day."

Apart from Ishmael Bernal, Campos also devoted one chapter each to filmmakers Mike de Leon and Kidlat Tahimik, which were highly enjoyable parts of the book. In each chapter, the reader will learn about the preoccupations of the filmmakers, and such discussions can even encourage the reader to watch their films. Campos explains that de Leon's films are feverishly anticipated as the director takes a long time before releasing a new one. One of the most anticipated of de Leon's works was Bayaning 3rd World (Third World Hero). The film was released after almost eight years since de Leon's last film. It centers on an intriguing concept as it is a film about filmmakers making a film about the national hero Jose Rizal. Through this metafictive method, Bayaning 3rd World poses questions such as: is it possible to make a film about Rizal? What's problematic about making a film about our national hero? Despite the film being highly anticipated by movie critics and film lovers, the movie did not earn well in the box office. This illustrates de Leon' curious position in the film industry. He is heralded as a genius but he flounders commercially.

As to Campos's chapter on Kidlat Tahimik, one can learn about the filmmaker's ownership of the "primitive" cinema. Often wearing a hand-painted shirt and a bahag (loincloth), Tahimik is also known for shooting with his "bamboo kamera," a camera that was formed using a number of locally-made woven baskets. His garb signifies his interests in tribal culture and his films reflect this. He often blends documentary techniques, at many times autobiographical and depicting his own family members, news footages, and filming Ifugao rituals that mainstream media ignores. An interesting example is Bakit Dilaw ang Gitna ng Bahaghari? (Why is Yellow the Middle of the Rainbow?). It begins with his family wanting to eat at McDonalds, and Tahimik expressing his helpless opposition to their food preference by cutting his hair. These shots are juxtaposed with a news item entitled "Fighting the Dictator in the US," and then Tahimik says "You're right, it's harder to fight the dictator in us than to fight the dictators in the US."

Kritika Kultura 28 (2017): -313

(C) Ateneo de Manila University

$<$ http://journals.ateneo.edu/ojs/kk/> 
All of these discussions were interesting to learn about, and then you remember that you are supposed to be reading about the end of national cinema. As though on cue, the discussions on the end of national cinema come back every now and then. Yet, mostly they come back as a mere blush, and often at the end of the chapters, like an afterthought. Furthermore, in many of such instances, Mr. Campos admits that the end of national cinema is not happening and is difficult to even ensure. Sprinkled in several chapters of the book, Campos admits that there are many factors that reinforce the system. He says that the national is inescapable, it is integral to the marketing of the film, how being rooted in cultural specificity is needed for understanding a film, how the national is a fixed juncture in film studies, and how film festivals encourage national cinemas through the need for specificity. With these discussions dominating the book, it should have been titled "The Endurance of National Cinema." Therefore, the key to enjoying this book is to ignore the expectations instigated by the title and the introductory chapter. Another is to to read it as a bunch of well-written essays on film that were strung together and not as a cohesive book on the end of national cinema. 